\title{
Megalobrama amblycephala grazes preferentially on Hydrilla verticillata but makes more efficient use of Vallisneria denseserrulata: implications for biological control of submerged macrophytes
}

\author{
Chunyu Yin ${ }^{1,2,3}$, Zhaoxia Wang ${ }^{2,3}$, Yu Zhao ${ }^{2,3}$, Yiming Gao ${ }^{2,3}$, Wei Zhen ${ }^{4}$, Xiaolin $\mathrm{He}^{5}$, \\ Chunsheng Yin $^{1}$ and Baohua Guan ${ }^{2,3, *}$ \\ ${ }^{1}$ Shanghai Ocean University, College of Marine Ecology and Environment, Shanghai 201306, PR China \\ 2 State Key Laboratory of Lake Science and Environment, Nanjing Institute of Geography and Limnology, Chinese Academy of \\ Sciences, Nanjing 210008, PR China \\ ${ }^{3}$ University of Chinese Academy of Sciences, Beijing 100049, PR China \\ ${ }^{4}$ Wuhan planning and Design Co., LT., Wuhan 430000, PR China \\ ${ }^{5}$ Belsun Aquatic Ecology Science and Technology Co., LT., Guangzhou 510000, PR China
}

Received: 28 February 2019 / Accepted: 14 May 2019

\begin{abstract}
Growth of the meadow-forming macrophyte Vallisneria denseserrulata is often negatively impacted as result of shading by the canopy-forming Hydrilla verticillata. Grazing by the herbivorous cyprinid Megalobrama amblycephala is thought to control $H$. verticillata. We hypothesized that $M$. amblycephala would prefer $H$. verticillata over $V$. denseserrulata, and that where the latter is grazed, its growth will not be wholly compromised, due in part to the efficiency with which it is metabolized by the grazer. In a pond experiment, macrophytes were planted with monocultures of $H$. verticillata and $V$. denseserrulata, and in mixed cultures of the two species, with and without grazing by $M$. amblycephala. The results showed that in the absence of fish, the growth rate of $V$. denseserrulata was significantly reduced in the presence of $H$. verticillata. In the mixture, $M$. amblycephala had a significant negative effect on the growth of $H$. verticillata but not on $V$. denseserrulata. Grazing was associated with reductions in plant height, plant fresh weight and leaf fresh weight but the leaf number, maximum root length, maximum blade width, root weight and stem weight in $V$. denseserrulata increased. The food utilization ratio of $M$. amblycephala was significantly higher when grazing solely on $V$. denseserrulata than when grazing on $H$. verticillata or the mixture. Our results imply that $V$. denseserrulata is protected from overgrazing by the ability of $M$. amblycephala to make more effective metabolic use of ingested material than for $H$. verticillata. Furthermore, $M$. amblycephala is beneficial to $V$. denseserrulata in reducing competition from H. verticillata.
\end{abstract}

Keywords: Submerged macrophytes / herbivorous fish / competition / utilization rate / growth morphology

Résumé - La croissance du macrophyte tapissant Vallisneria denseserrulata est souvent affectée négativement par l'ombrage causé par Hydrilla verticillata qui forme une canopée. Le broutage par le cyprinidé herbivore Megalobrama amblycephala est censé contrôler $H$. verticillata. Nous avons émis l'hypothèse que $M$. amblycephala préférerait $H$. verticillata à $V$. denseserrulata, et que lorsque ce dernier est brouté, sa croissance ne sera pas entièrement compromise, en partie à cause de l'efficacité avec laquelle il est métabolisé par le brouteur. Dans une expérience en étang, des macrophytes ont été plantés en monocultures de $H$. verticillata et $V$. denseserrulata, et en cultures mixtes des deux espèces, avec et sans broutage par $M$. amblycephala. Les résultats ont montré qu'en l'absence de poisson, le taux de croissance de $V$. denseserrulata était significativement réduit en présence de $H$. verticillata. Dans le mélange,

\footnotetext{
*Corresponding author: bhguan@niglas.ac.cn
} 
M. amblycephala a eu un effet négatif significatif sur la croissance de $H$. verticillata mais pas sur $V$. denseserrulata. Le broutage a été associé à une réduction de la taille des plantes, du poids frais des plantes et du poids frais des feuilles, mais le nombre de feuilles, la longueur maximale des racines, la largeur maximale du limbe, le poids des racines et le poids des tiges chez $V$. denseserrulata ont augmenté. Le taux d'utilisation de la nourriture de $M$. amblycephala était significativement plus élevé lorsqu'il broutait uniquement sur $V$. denseserrulata que lorsqu'il broutait sur $H$. verticillata ou le mélange. Nos résultats impliquent que $V$. denseserrulata est protégé du surbroutage par la capacité de $M$. amblycephala à faire un usage métabolique plus efficace du matériel ingéré que pour $H$. verticillata. De plus, $M$. amblycephala est bénéfique pour $V$. denseserrulata en réduisant la concurrence de $H$. verticillata.

Mots clés: Macrophytes submergés / poissons herbivores / compétition / taux d'utilisation / morphologie de croissance

\section{Introduction}

Canopy-forming submerged macrophytes typically outcompete sympatric meadow-forming species for light (Van et al., 1999). Hydrilla verticillata, a fast-growing canopyforming species, thrives in shallow eutrophic lakes and can drive rapid improvements in water transparency (Langeland, 1996; Bianchini et al., 2010). However, massive growth of $H$. verticillata can also limit the availability of light and oxygen in the lower layers of the water column, resulting in an overall adverse effect on water quality (Hilt et al., 2006). Shading by $H$. verticillata can be detrimental to the growth of meadow-forming submerged macrophytes such as Vallisneria denseserrulata, whose biomass is concentrated in the lower layers of the water column (Gopal and Goel, 1993). $V$. denseserrulata is also commonly used in lake restoration, since it forms a network of well-developed roots that help to bind the substratum, maintaining stability and reducing the resuspension of sediment (Hayashi et al., 1988; Smith and Adams, 1986; Valk, 2006). Therefore, in order to improve the water quality of eutrophic lakes, it is necessary to inhibit competition from $H$. verticillata in areas successfully colonized by $V$. denseserrulata.

Methods currently employed to control massive overgrowth of canopy-forming submerged macrophytes include physical (artificial and mechanical), chemical and biological measures (Hussner et al., 2017). Among the latter, the use of herbivorous fish is generally considered to be an environmentally friendly, economic and natural choice. The Wuchang bream, Megalobrama amblycephala, is a medium-sized cyprinid native to the Yangtze Basin. Its small mouth and throat teeth, modest food intake and relative slow growth allow it to feed on aquatic plants without inflicting serious damage (Cao, 1960) and it is therefore favored over many other herbivorous aquatic organisms as an agent of biological control for submerged macrophytes (Lodge, 1991; Van et al., 1998; Bonar et al., 2002; Ganthy et al., 2015).

Plants of $H$. verticillata are characterized by high water content, soft texture and low concentrations of allelochemicals, making them attractive to herbivorous fish (Leslie et al., 1987). However, while this preference often results in a greater biomass or number of plants being consumed, it doesn't necessarily follow that the food has a higher utilization rate in terms of fish growth. For example, gilthead seabream (Sparus aurata) fed on lower protein and low crude protein diets exhibited higher rates of total lipid utilization (Fulvio et al., 2014). When the utilization rate of food is high, grazing rates tend to be low, resulting in less damage to macrophytes.

A study by Zhen et al. (2018) suggested that $M$. amblycephala grazing on $H$. verticillata consume greater biomass than conspecifics grazing on $V$. denseserrulata. The same study demonstrated that while $V$. denseserrulata is grazed by $M$. amblycephala, the impact is limited to the extent that total biomass of $V$. denseserrulata in a system can still increase. We therefore hypothesized that despite its apparent predilection for $H$. verticillata, M. amblycephala would exhibit a higher food utilization rate when grazing on $V$. denseserrulata. Such a scenario would be highly conducive to the biological control of $H$. verticillata and the protection of $V$. denseserrulata. We designed a pond experiment with three groups: monocultures of $V$. denseserrulata and $H$. verticillata and a mixed culture of both species. The growth of plants in each group was tested with and without the presence of grazing M. amblycephala.

\section{Materials and methods}

The experiments were conducted from March to July 2015 in a former fish pond $\left(30^{\circ} 22^{\prime} 49.84^{\prime \prime} \mathrm{N}, 114^{\circ} 22^{\prime} 49.84^{\prime \prime} \mathrm{E}\right)$ near Wuhan City, Hubei Province (China). The pond had an area of about $6000 \mathrm{~m}^{2}$ and no aquatic vegetation prior to the experimental planting. Fish was removed and the pond was drained but not dredged, then refilled with clear water to a depth of $1 \mathrm{~m}$.

The pond was divided into three equal sections (referred to hereafter as the eastern, central and western thirds) using nylon netting. In March, individuals of $V$. denseserrulata were planted evenly in the western third of the pond, clusters of $H$. verticillata with the same fresh weight as individual $V$. denseserrulata were planted in the eastern third of the pond. The central third of the pond was then planted with both $V$. denseserrulata and $H$. verticillata, interspersed at a ratio of 1 individual: 1 cluster. All plants were located at $16-18 \mathrm{~cm}$ intervals in all three treatments. The macrophytes grew without disturbance for about two months, and by May, both species had achieved full vegetative growth. At that time, 24 nylon mesh enclosures $(2.0 \mathrm{~m}$ long $\times 2.0 \mathrm{~m}$ wide $\times 1.5 \mathrm{~m}$ height with bore diameter of $1 \mathrm{~cm} \times 1 \mathrm{~cm}$ ) were used to 
A

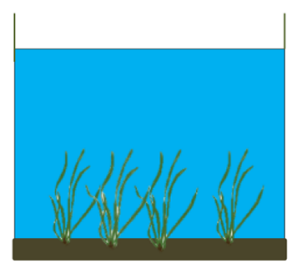

D

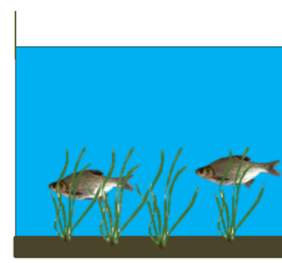

V. denseserrulata
B

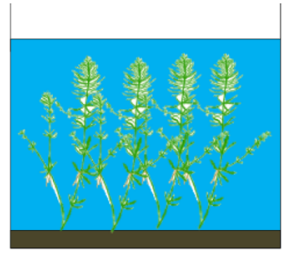

$\mathbf{E}$

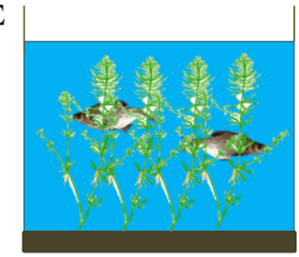

H. verticillata

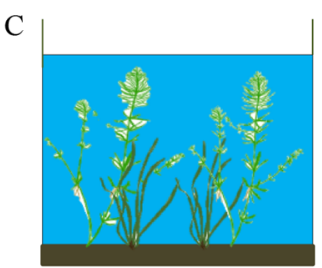

F

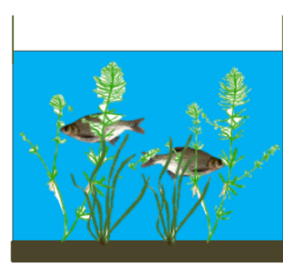

M. amblycephala

Fig. 1. Diagrammatic representation of the experimental setup ( $V$. denseserrulata is Vallisneria denseserrulata; $H$. verticillata is Hydrilla verticillate; M. amblycephala is Megalobrama amblycephala).

separate the three groups, referred to hereafter as mono- $H$. verticillata, mono- $V$. denseserrulata and mixed, with eight separately enclosed replicates for each group. Within different plant treatments, four replicates were selected at random to receive two 1-year-old specimens of Wuchang bream, M. amblycephala. The nylon nets allowed water to flow freely around the pond, ensuing identical nutrient levels in all treatments, but preventing free movement of introduced fish. At the beginning of the experiment, the average total nitrogen (TN), total phosphorus (TP) and Chlorophyll $a$ concentrations in the water were $0.53 \mathrm{mg} / \mathrm{L}$, $0.21 \mathrm{mg} / \mathrm{L}$ and $10.57 \mu \mathrm{g} / \mathrm{L}$, respectively. The enclosures were fixed in the sediment with bamboo poles, the upper parts were open to the air, and the bottom parts were weighted into the sediment with steel bars. The experimental setup is illustrated in Figure 1. M. amblycephala were transported from the Wuxi Freshwater Fishery Center to an adjacent pond 15 days before the experiment began and allowed to acclimatize with no feeding. Before being introduced to the experimental enclosures, eight individuals of $M$. amblycephala were selected at random for measurement of initial body length and body weight. The average length of the fish was $22.08 \pm 0.60 \mathrm{~cm}$, and the average weight was $117.76 \pm 10.68 \mathrm{~g}$.

Macrophyte samples were selected randomly by a $50 \mathrm{~cm} \times 50 \mathrm{~cm}$ plot adjacent the experimental enclosures at the beginning of the experiment in order to provide estimates of the biomass of the macrophytes in the enclosures. At the end of the experiment, the plants in all treatment enclosures were collected. All sampling was carried out by hand by divers who uprooted all plants within the sampling frame $(50 \mathrm{~cm} \times 50 \mathrm{~cm}$ at beginning and $2 \mathrm{~m} \times 2 \mathrm{~m}$ at ending). As soon as the macrophyte samples were brought back to the laboratory, they were washed with tap-water and the fresh biomass of submerged macrophytes from each experimental treatment was weighed. Furthermore, in order to determine changes in the growth of individual $V$. denseserrulata after grazing by $M$. amblycephala, we measured biometric indices for 10 plants selected at random from the mono- $V$. denseserrulata groups with fish, both before and after the experiment. Measurements were taken of plant height, plant weight, leaf number, maximum root length, maximum blade width, leaf thickness, root weight, stem weight and leaf weight. At the end of the experiment, all $M$. amblycephala from the fish treatments were recaptured and their body lengths and weights were recorded.

All the data, including the biological indicators from plants and fish were processed and analyzed in Microsoft Office Excel, and curves of changes were plotted. The significance of differences observed in each treatment group was tested by $T$-test after the normality of variable distribution of all data was proven with SPSS 22.

\section{Results}

\subsection{Rate of biomass accumulation in submersed macrophytes}

Our results show that in ungrazed (fish free) treatments, the rate of biomass loss in $H$. verticillata was significantly $(P<0.05)$ lower in the mixed culture than that in the monoculture (Fig. 2A). After the addition of M. amblycephala, the biomass accumulation rate of $H$. verticillata in both the mono- and the mixed cultures declined significantly faster than in the fish free treatments $(P<0.05)$. 

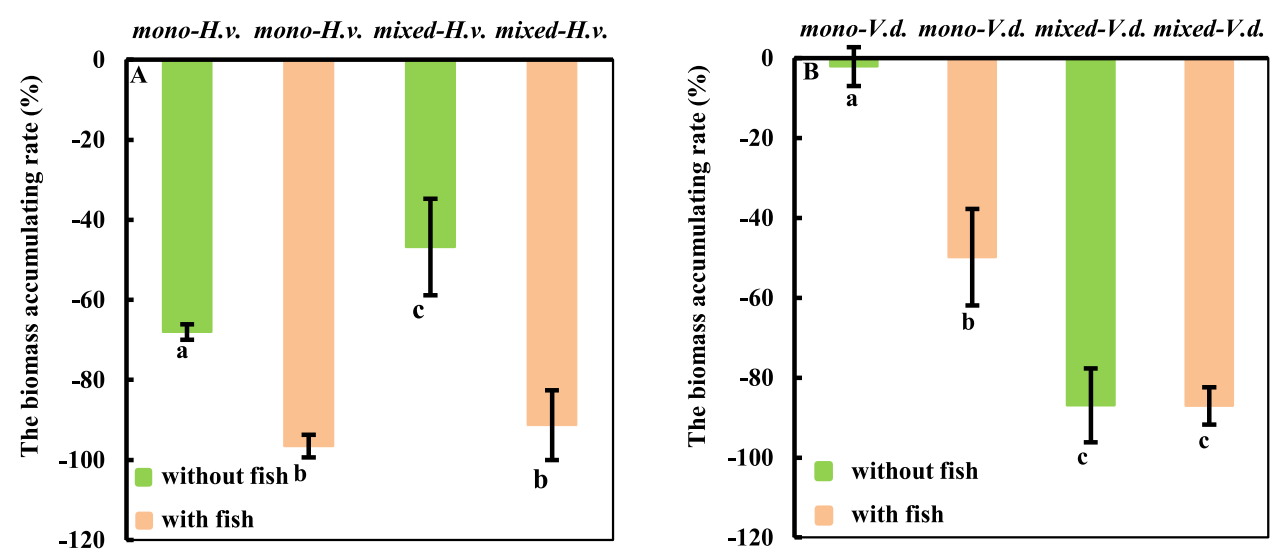

Fig. 2. Biomass accumulation rate of Hydrilla verticillata (A) and Vallisneria denseserrulata (B) in mono- and mixed culture treatments. Differing letters above the bars indicate statistically significant differences between the four groups $(P<0.05)$. Mean $\pm \mathrm{SE}$.
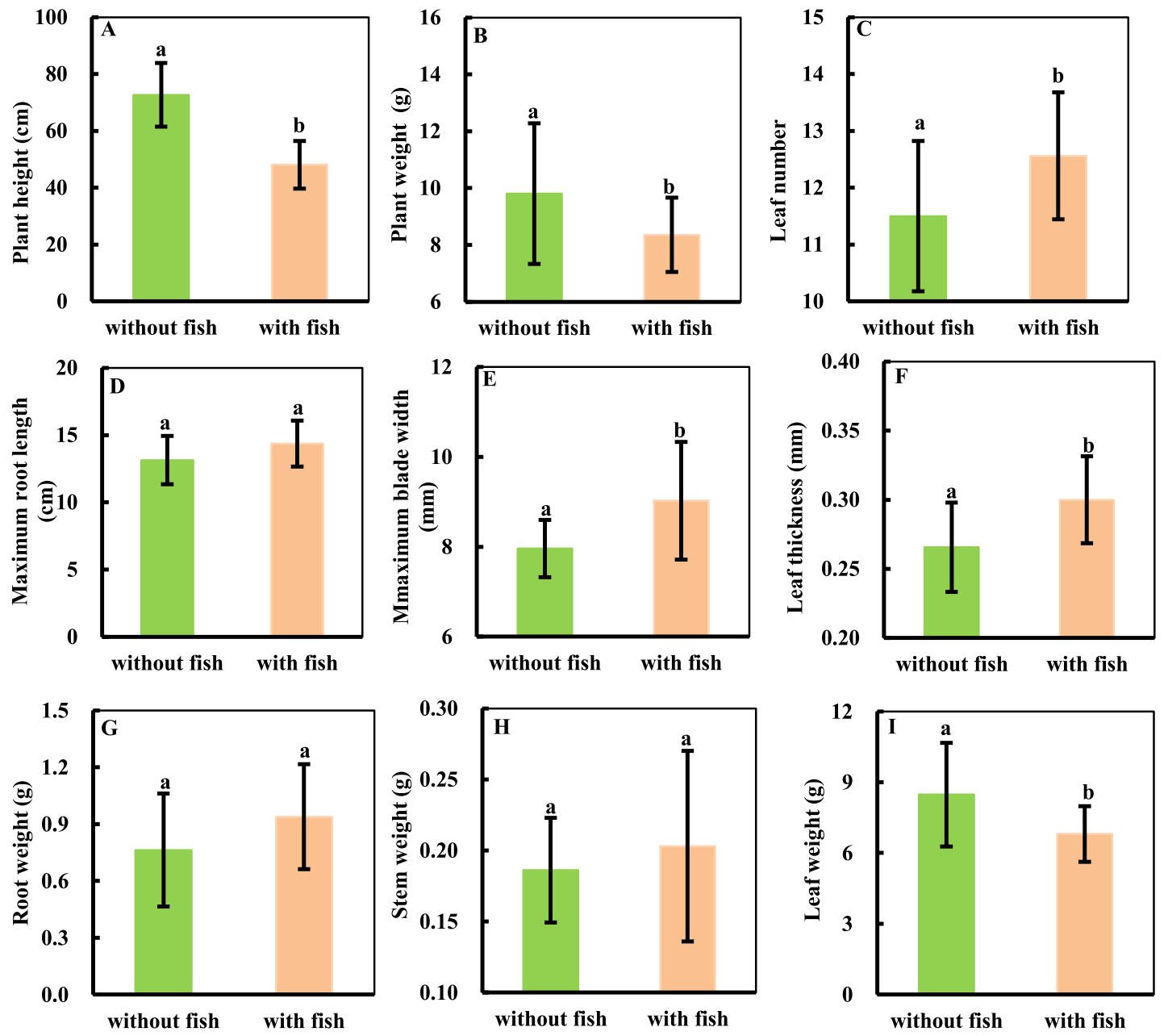

Fig. 3. The effect of Megalobrama amblycephala presence on growth morphology of Vallisneria denseserrulata. A, plant height; B, plant weight; C, leaf number; D, maximum root length; E, maximum blade width; F, leaf thickness; G, root weight; H, stem weight; I, leaf weight. Differing letters above the bars indicate statistically significant differences between two groups $(P<0.05)$. Mean \pm SE. 

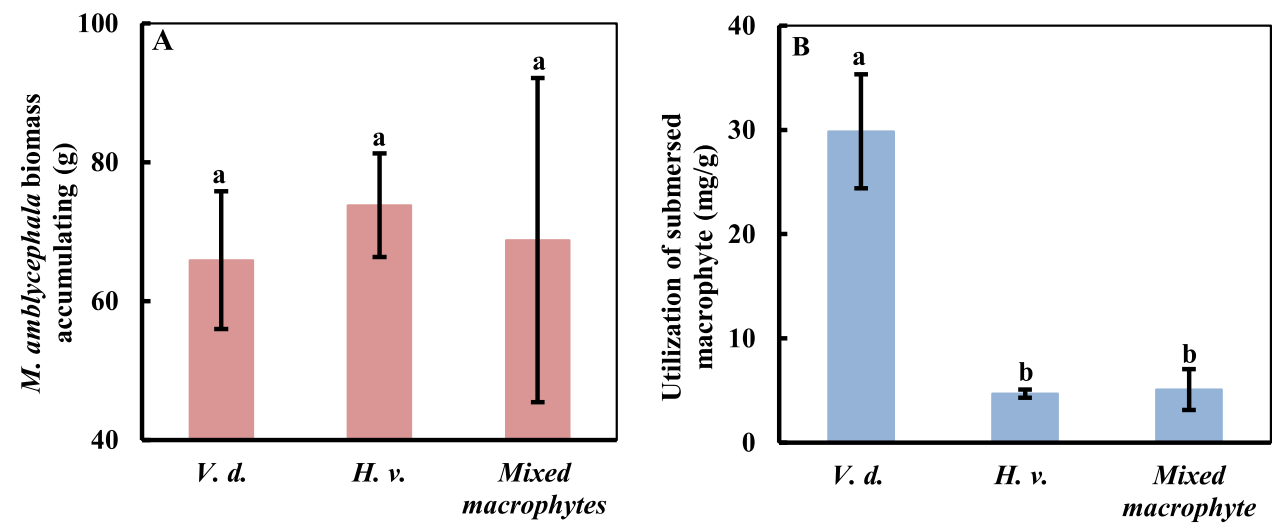

Fig. 4. Fresh biomass gains in Megalobrama amblycephala (A) and utilization rates of submersed macrophytes (mg/g) by M. amblycephala (B). $V . d$. is Vallisneria denseserrulata in the figure. H. v. is Hydrilla verticillata. Differing letters above the bars indicate statistically significant differences between the three groups $(P<0.05)$. Mean \pm SE.

In the absence of fish, the rate of biomass accumulation of $V$. denseserrulata was significantly reduced when it grew alongside $H$. verticillata $(P<0.05$; Fig. $2 \mathrm{~B})$, suggesting that $H$. verticillata has a significant inhibitory effect on the growth of $V$. denseserrulata. Following the introduction of $M$. amblycephala, the biomass accumulation rate of monocultured $V$. denseserrulata declined significantly $(P>0.05)$, but in the mixed culture there was almost no change. Thus, $M$. amblycephala had no significant effect on the growth of $V$. denseserrulata plants interspersed with $H$. verticillata.

\subsection{Morphology of $\boldsymbol{V}$. denseserrulata}

At the end of the experiment, morphological differences were observed between specimens of monocultured $V$. denseserrulata grown with and without fish. Plant height, plant weight and leaf weight all decreased significantly under grazing pressure from $M$. amblycephala, while leaf number, maximum blade width and leaf thickness all increased significantly $(P<0.05)$. Maximum root length, root weight and stem weight also increased in the presence of fish, but not significantly $(P>0.05)$.

\subsection{Fish growth and metabolic utilization of submerged macrophytes}

At the end of the experiment, the fresh weight of $M$. amblycephala maintained in the mono- $V$. denseserrulata treatment was smaller than that of fish kept in the mono- $H$. verticillata treatment and the mixed culture, but the difference was not deemed significant $(P>0.05$; Fig. 4$)$. However, the metabolic utilization of $V$. denseserrulata by fish was significantly greater than that of $H$. verticillata or of a mixed macrophyte diet $(P<0.05)$.

\section{Discussion}

According to our results, biomasses of $H$. verticillata decreased in both monoculture and mixed treatments, even in the absence of $M$. amblycephala, because the experiment commenced at a season when with the plants in a state of vigorous vegetative growth. The biomass of ungrazed, monocultured $V$. denseserrulata also decreased very slightly. However, in the mixed fish-free treatment, the loss of $V$. denseserrulata biomass was significant. These results indicate that $M$. amblycephala has an obvious inhibitory effect on $H$. verticillata biomass in both mono- and mixed cultures. The results also indicate that in the absence of fish grazing pressure, shading by the canopy-forming $H$. verticillata inhibits the growth of the meadow-forming $V$. denseserrulata, supporting the conclusions of Xiao et al. (2007) and Tang et al. (2019).

Following the introduction of $M$. amblycephala, the loss of $V$. denseserrulata biomass increased significantly in monoculture, but not in mixed culture. Meanwhile, the biomass losses of $H$. verticillata increased significantly under grazing pressure in both mono- and mixed cultivation. This result suggests a significant preference of $M$. amblycephala for the soft growth of $H$. verticillata over $V$. denseserrulata, such that the latter was only targeted when it was the only food option. Grazing by $M$. amblycephala is also shown to influence the growth morphology of $V$. denseserrulata, the leaves of which became wider, thicker and more numerous in the fish treatments. The results indicate that grazing by $M$. amblycephala results in short, lightweight individuals of $V$. denseserrulata with reduced total leaf biomass but with larger, thicker and more numerous leaves near the sediment. The aboveground biomass of $V$. denserrulata declined in the presence of $M$. amblycephala, but the biomass distribution value per unit height increased (Li et al., 2010). These morphological changes amount to denser plant growth close to the sediment. Previous research suggests that this kind of change can reduce rates of $V$. denseserrulata consumption by small fish and help to slow biomass losses (Valentine et al., 1997; Pípalová, 2006; Planes et al., 2011).

The utilization rate of $V$. denseserrulata by $M$. amblycephala was significantly higher than that of $H$. verticillata or of mixed macrophytes. In other words, M. amblycephala consumed less $V$. denseserrulata than $H$. verticillata to achieve the same body weight (Ganga et al., 1985). The results suggest that grazing by $M$. amblycephala can be beneficial in decreasing the biomass of $H$. verticillata without concomitant damage to $V$. denseserrulata. 
Overall, the results of the current study suggest that the grazing preference for $H$. verticillata shown by $M$. amblycephala could protect $V$. denseserrulata in the community by reducing shading. Meanwhile, under grazing by $M$. amblycephala, $V$. denseserrulata is likely to adopt a shorter and sturdier growth form, which could also be beneficial in reducing losses to other small herbivorous fish (Gail and Kenneth, 2003; Li et al., 2010). Moreover, the high utilization rate of $V$. denseserrulata by $M$. amblycephala further reduces the damage to the former, shifting competitive advantage further towards the meadow-forming species and suggesting the latter is a highly suitable agent of biological control where the macrophyte community is threatened by overgrowth of $H$. verticillata.

Acknowledgments. This research was financially supported by the National Natural Science Foundation of China (NSFC; Grant Nos. 31100341 and 31270409) and the Science and Technology Service Network Initiative of the Chinese Academy of Sciences (Grant No. KFJ-STS-ZDTP-038). We thank all colleagues from Belsun Aquatic Ecology Science and Technology Cooperation Limited for setting up the experimental facilities and helping us sample our experiments. We greatly appreciate the comments and suggestions from the reviewers and the editor in charge. We also thank Dr Amy-Jane Beer very much for polishing the language twice.

\section{References}

Bianchini I, Cunha-Santino, MB, Milan, JAM, Rodrigues CJ, Dias JHP. 2010. Growth of Hydrilla verticillata (Lf) Royle under controlled conditions. Hydrobiologia 644: 301-312.

Bonar SA, Bolding B, Divens M. 2002. Effects of triploid grass carp on aquatic plants, water quality, and public satisfaction in Washington State. North Am J Fish Manag 22: 96-105.

Cao W. 1960. A biological study of Megalobrama amblycephala and Megalobrama terminalis of Lake Liangzi. Acta Hydrobio Sinica (in Chinese) 1: 57-82.

Fulvio M, Alessio B, Ramon F, Lorenzo M, Anna B, Erika B, Luca P. 2014. Effects of dietary lipid level on growth and feed utilisation of Gilthead Seabream (Sparus Aurata L.) reared at mediterranean summer temperature. Ital J Anim Sci 13: 29-34.

Gail TF, Kenneth A. 2003. Interactive effects of light and salinity stress on the growth, reproduction, and photosynthetic capabilities of Vallisneria americana (wild celery). Estuar Coast 26: 1255-1268.

Ganga G, Sulochana CJ, Senthamil SR, Manoharan T. 1985. Influence of food plants on the food utilization and chemical composition of Henosepilachna septima (Coleoptera: coccinellidae). Proc Anim Sci 94: 161-167.

Ganthy F, Soissons L, Sauriau PG, Verney R, Sottolichio A. 2015. Effects of short flexible seagrass Zostera noltei on flow, erosion and deposition processes determined using flume experiments. Sedimentology 62: 997-1023.

Gopal B, Goel U. 1993. Competition and allelopathy in aquatic plant communities. Botan Rev 59: 155-210.
Hayashi H, Maehara R, Hirabayashi K. 1988. Growth of Elodea muttallii and changes of phosphorus in Lake Kizaki (in Japanese). Bull Limnol Soc Ko-Shin-Etsu District 13: 27-32.

Hilt S, Gross EM, Hupfer M, Morscheid H, Maehlmann J, Melzer A, Poltz J, Sandrock S, Scharf EM, Schneider S, van de Weyer K. 2006. Restoration of submerged vegetation in shallow eutrophic lakes - a guideline and state of the art in Germany. Limnologica 36: $155-171$.

Hussner A, Stiers I, Verhofstad MJJM, Bakker ES, Grutters BMC, Haury J, van Valkenburg JLCH, Brundu G, Newman J, Clayton JS, Anderson LWJ, Hofstra D. 2017. Management and control methods of invasive alien freshwater aquatic plants: a review. Aquat Bot 136: 112-137.

Langeland KA. 1996. Hydrilla verticillata (LF) Royle (Hydrocharitaceae), "the perfect aquatic weed". Castanea 61: 293-304.

Leslie AJ, Dyke JMV, Hestand III RS, Thompson BZ. 1987. Management of aquatic plants in multiuse lakes with grass carp (Ctenopharyngodon idella). Lake Reservoir Manage 3: 266-276.

Li K, Liu Z, Gu B. 2010. Compensatory growth of a submerged macrophyte (Vallisneria spiralis) in response to partial leaf removal: effects of sediment nutrient levels. Aquat Ecol 44: 701-707.

Lodge DM. 1991. Herbivory on freshwater macrophytes. Aquat Bot 41: $195-224$.

Pípalová I. 2006. A review of grass carp use for aquatic weed control and its impact on water bodies. Aquat Plant Manag 44: $1-12$.

Planes S, Raventos N, Ferrari B, Alcoverro T. 2011. Fish herbivory leads to shifts in seagrass Posidonia oceanica investments in sexual reproduction. Mar Ecol Prog Ser 431: 205-213.

Smith CS, Adams MS. 1986. Phosphorus transfer from sediment by Myriophyllum spicatum. Limnol Oceanogr 31: 1312-1321.

Tang Y, Fu B, Zhang X, Liu Z. 2019. Nutrient addition delivers growth advantage to Hydrilla verticillata over Vallisneria natans: a mesocosm study. Knowl Manag Aquat Ecosyst 420: 12.

Valentine JF, Heck KL, Busby J, Web, D. 1997. Experimental evidence that herb-ivory increases shoot density and productivity in a subtropical turtlegrass (Thalassia testudinum) meadow. Oecologia 112: 193-200.

Valk AGV. 2006. The biology of fresh water wetlands. Oxford: OUP, pp. 113-145.

Van TK, Wheeler GS, Center TD. 1998.Competitive interactions between Hydrilla (Hydrilla verticillata) and Vallisneria (Vallisneria americana) as influenced by insect herbivory. Biol Control 11: $185-192$.

Van TK, Wheeler GS, Center TD. 1999. Competition between Hydrilla verticillata and Vallisneria americana as influenced by soil fertility. Aquat Bot 62: 225-233.

Xiao K, Yu D, Xu X, Xiong W. 2007. Benefits of clonal integration between interconnected ramets of Vallisneria spiralis in heterogeneous light environments. Aquat Bot 189: 76-82.

Zhen W, Zhang X, Guan B, Yin C, Yu J, Jeppesen E, Zhao X, Liu Z. 2018. Stocking of herbivorous fish in eutrophic shallow clear-water lakes to reduce standing height of submerged macrophytes while maintaining their biomass. Ecol Eng 113: 61-64.

Cite this article as: Yin C, Wang Z, Zhao Y, Gao Y, Zhen W, He X, Yin C, Guan B. 2019. Megalobrama amblycephala grazes preferentially on Hydrilla verticillata but makes more efficient use of Vallisneria denseserrulata: implications for biological control of submerged macrophytes. Knowl. Manag. Aquat. Ecosyst., 420, 30. 